\title{
$\mathrm{DASH}$ 로 평가한 상지 근골격계 질환자의 기능 제한
}

김 규 상 $\cdot$ 장 기 언 ${ }^{2}$

${ }^{1}$ 한국산업안전보건공단 산업안전보건연구원 / ${ }^{2}$ 한림대학교 의과대학 재활의학교실

\section{Determining the Degree of Disability in Workers with Upper Limb Musculoskeletal Disorders using DASH}

\author{
Kyoo Sang Kim ${ }^{1}$, Ki Un Jang ${ }^{2}$ \\ ${ }^{1}$ Occupational Safety and Health Research Institute, KOSHA, Incheon, 403-711 \\ ${ }^{2}$ Department of Rehabilitation Medicine, Hallym University Medical College, Seoul, 150-719
}

\begin{abstract}
This study aimed to examine the development and characteristics of the workers with upper limb musculoskeletal symptoms and disorders and to analyze the upper limb musculoskeletal symptoms and disorders for its relationship with the individual socio-demographic characteristics. This study investigated the effect on the limitations of physical activities using standardized surveillance tool and clinical diagnosis. Musculoskeletal symptoms and the limitations of physical activities were examined. The clinical diagnosis of musculoskeletal disorders were carried out by physical examination, radiological examination and electromyography-electroneuronography for 22 workers in kitchen hood assembly process and 50 workers in toggle process of leather product manufacturing. The proportion of workers with musculoskeletal disorders was higher and the DASH score was also statistically higher in female and aged workers with longer working hours, longer household working hours, less leisure/hobby activity and higher physical load. Physical activities component score increased in the following order: workers in normal health, workers with musculoskeletal symptoms, and workers with musculoskeletal disorders as clinically diagnosed. Score for each DASH component increased in the following order: sports/performing arts ability, social activities, specific physical functional activities, work or other regular daily activities, work ability, psychological activities, insomnia and upper limb symptoms. The overall and each component DASH scores were higher in workers with symptoms of status praesens and of more severity, and receiving medical intervention. Musculoskeletal symptoms and disorders are associated with individual socio-demographic characteristics, and DASH score for physical activities of upper limb was higher in workers with musculoskeletal disorders. Musculoskeletal symptoms and disorders have a remarkable epidemiological significance for physical activities, social activities, work or other regular daily activities, upper limb symptoms and insomnia, where work ability, sports/performing arts ability and preventive measure is needed.
\end{abstract}

Keyword: DASH, Upper extremity musculoskeletal disorders, Upper limb symptoms

교신저자: 김규상

주 소: 403-711 인천광역시 부평구 구산동 34-4, 전화: 010-5766-6048, E-mail: kobawoo@kosha.net 


\section{1. 서 론}

직업성 근골격 질환 중에서 상지에 호발하는 질환은 수근 관증후군, 외측상과염, 근막통증후군, 건초염, 추간판탈출증 등이 있고, 질환 발생에 영향을 주는 3 대 인자는 반복성, 힘의 강도, 작업 자세로 알려져 있다.

이러한 상지 근골격계 질환은 일/작업 관련 활동의 제한 만이 아니라 일상생활에서의 동작수행능력의 어려움과 스 포츠/예술활동 관련에서도 영향을 미칠 수 있다. 실제 작업 장 근로자에서 근골격계 통증을 호소하는 증상자와 여러 다양한 상지 근골격계 질환자의 일상생활에서의 동작수행 능력 장애와 스포츠/예술 관련 사회적 활동의 제한을 보고 하고 있다(Fan 등, 2008; Kitis 등, 2009). 동작수행능력 조사는 개인의 주관적인 상지 동작의 제약 및 상지의 하나 또는 여러 부위의 장애 측정을 위해 만든 설문지인 DASH (Disability of the Arm, Shoulder and Hand) 가 많이 활용 되고 있다. $\mathrm{DASH}$ 는 여러 집단 또는 개인에서 상지 근골격 계 질환의 영향을 비교하여 구분하고, 치료 개입의 효과나 또는 시간의 경과에 따른 변화를 평가하기 위하여 개발되었 다(Solway 등, 2002). 또한 여러 나라에서 제조업체 근로 자, 근골격계 증상자 및 상지 질환자를 중심으로 이 도구의 적용과 더불어 신뢰도(Turchin 등, 1998; Beaton 등, 2001) 와 타당도(Beaton 등, 2000; Beaton 등, 2001)이 입증되 었으며, 상지 질환자의 물리치료(Fayad 등, 2008; Lucado 등; 2008), 입원전-후(Wong 등, 2007) 및 수술전-후의 평가도구(McDermid 등, 2006)로서 가장 널리 임상적으로 활용되고 있다.

상지 근골격계 질환자의 $\mathrm{DASH}$ 를 이용한 동작수행능력 장애에 대한 외국에서의 연구 결과를 보면, 상지 근골격계 질환으로 인해 일/작업 수행뿐 아니라 일상 사회생활의 활 동에도 영향을 끼쳐 제약을 가져오게 됨을 보고하고 있다. 현재 우리나라에서 근골격계 증상이 근무와 관련하여 어떤 요인이 근골격계 질환을 유발하는가에 대한 연구는 많이 수 행되었으나, 근골격계 증상이 근무환경 외에 다른 일상 사회 생활에 미치는 영향에 대한 연구는 김규상 등(2009)의 연 구가 유일하다.

이 연구는 주방용 후드 조립공정과 피혁제품 제조의 토글 공정 근로자에서 상지, 특히 수부 근골격계 질환이 다수 발 생하여 표준화된 측정도구를 이용한 근골격계 증상, 동작수 행능력의 제한을 조사하고, 이학적 검사, 방사선 검사 및 근 육신경전도 검사 등 근골격계 질환의 임상의학적 진단을 시 행하여 상지 근골격계 증상 및 질환자의 발생과 특성 등을 살펴보고자 하였다. 그리고 상지 근골격계 증상 및 질환의 개인의 사회인구학적 특성과의 관련 및 동작수행능력의 제
한에 어떠한 영향을 미치는지 분석하고자 하였다.

\section{2. 대상 및 방법}

\section{1 연구 대상}

이 연구의 조사 대상은 충북 영동 소재의 주방기기 및 욕 실생활용품 제조 1 개 회사의 주방용 후드 조립공정의 22 명 과 청주공단에 위치한 피혁제품 제조 1 개 공장의 토글공정 근로자 50 명 등 2 개 사업체 총 72 명이다. 토글공정은 가죽 의 수율 증대를 위해 주름을 펴고 최종 건조시키는 작업으로 주로 여성 근로자들이 작업을 수행한다. 작업 내용은 반입 적재 대차로부터 젖은 가죽을 들어 올려 컨베이어식 작업대 위에 펼쳐 놓고, 토글 집게들을 이용하여 가죽을 신전 고정 하는 작업과 건조대에서 마른 가죽은 토글 집게를 해체하여 반출 적재 대차로 이동하는 작업을 반복적으로 수행한다. 이 연구는 위 사업장의 주방용 후드 조립공정과 피혁제품 제조 의 토글공정 근로자 중 일부에서 손가락 관절이 휘는 등 근 골격계 질환 의심자가 다수 발견되어 수행하게 되었다.

\section{2 연구 방법}

연구 대상 공정과 작업자에 대한 산업의학적 조사로 증상 설문조사, 상지의 동작수행능력 조사, 이학적 검사, 방사선 검사(both hand AP \& Oblique, wrist/elbow AP \& lateral), 근전도 검사 등을 시행하였다.

근골격계 증상 조사는 근골격계 증상 조사표(근골격계 부담작업 유해요인조사 지침, KOSHA Code $\mathrm{H}-30-2003$, 한국산업안전공단, 2003)를 이용하였다. 이 조사표를 이용하 여 성별, 연령, 근무 기간, 결혼 여부, 여가취미활동, 평균 가사노동시간, 과거 질병력, 과거 사고력, 육체적 부담 정도 를 조사하였다. 과거 질병력은 근골격계 질환의 증상 발생에 영향을 미칠 수 있는 류마티스 관절염, 당뇨병, 루프스병, 통풍, 알코올 중독 등에 대해 조사하였으며, 과거 사고력은 운동 혹은 사고(교통사고, 넘어짐, 추락 등)로 인해 손/손가 락/손목, 팔/팔꿈치, 어깨, 목, 허리, 다리/발 부위를 다친 적 이 있는지 조사하였다. 근골격계 증상은 지난 1 년 동안 목. 어깨, 팔/팔꿈치, 손/손가락/손목, 허리, 다리/발 중 어느 한 부위라도 작업과 관련하여 통증이나 불편함(통증, 쑤씨는 느 낌, 뺏뼛함, 화끈거리는 느낌, 무감각 혹은 찌릿찌릿함 등) 을 느낀 적이 있는가를 조사하였다. 근골격계 증상은 통증의 부위에 따라 통증의 지속 기간, 통증의 정도, 통증의 빈도, 현증 여부 및 통증에 대한 조치로 구분하여 분류하였다. 지 난 1 년간 기간 중 증상 호소(증상 $\mathrm{I}$ ), 지난 1 주간 현 증상 
호소(증상 II), 통증 기간이 1 주일 이상이거나 통증의 빈도 가 1 달에 1 번 이상이면서 중간 통증(작업 중 통증이 있으 나 귀가 후 휴식을 취하면 괜찮은 정도) 이상을 호소(증상 III), 증상 III과 더불어 지난 1 주일 동안에도 이러한 증상 이 있는 경우(증상 IV), 통증 기간이 1 주일 이상이거나 통 증의 빈도가 1 달에 1 번 이상이면서 심한 통증(작업 중 통 증이 비교적 심하고 귀가 후에도 통증이 계속되는 경우) 이상을 호소한 경우 (증상 $\mathrm{V}$ ), 증상 $\mathrm{V}$ 과 더불어 지난 1 주일 동안에도 이러한 증상이 있는 경우(증상 $\mathrm{VI}$ ) 및 증상 $\mathrm{VI}$ 에 의학적 조치를 한 경우(증상 VII)로 구분하여 살펴보았다. 상지 증상은 어깨, 팔/팔꿈치, 손/손각락/손목 중 어느 한 부 위라도 증상을 호소한 경우로 정의하였다.

동작수행능력 조사는 개인의 주관적인 상지 동작의 제약 및 상지의 하나 또는 여러 부위의 장애 측정을 위해 만든 설문지인 DASH(Disability of the Arm, Shoulder and Hand)를 이용하였다. 이 조사는 2004년도의 우리나라 번 역판을 이용하여 조사하였다.

$\mathrm{DASH}$ 의 설문은 증상 및 특정한 동작을 수행하는 능력에 관한 질문으로 구성되어 있다. 지난 주 상태를 기준으로 답 변하며, 만약 지난 주 동안 질문한 동작을 할 기회가 없었다 면, 상태에 가장 가까운 답변에 표시하도록 하였다. 어느 쪽 손이나 팔을 쓰는지는 중요하지 않으며, 어떻게 동작을 수 행하는지에 관계없이 수행능력을 기준으로 답변하도록 하였 다. DASH 설문지는 동작수행능력 평가의 30 문항, 선택사 항으로 작업 관련 설문 4 문항, 스포츠/예술활동 관련 설문 4 문항으로 총 38 문항으로 구성되어 있다.

이 연구에서는 동작수행능력 평가 항목 30문항을 활동기 능상의 구체적인 동작수행능력의 제한, 상지장애로 인한 사 회활동과 일상활동 제한, 증상의 정도, 상지의 통증으로 인 한 수면장애, 상지장애로 인한 (정신)심리적 영향(능력 감퇴, 자신감 감퇴 및 쓸모없음) 등으로 구분하여 살펴보았다.

상지 근골격계 질환의 임상의학적 진단은 이학적 검사, 근전도 검사 및 방사선 검사 등을 통해 수행하였다. 수지관 절의 골관절염의 진단은 방사선상 관절의 양성 변화를 판단 기준으로 하였다. 즉, 관절간격 협소화, 골극형성, 아탈구, 각형성 및 관절유합이 있는 경우를 진단 양성 기준으로 하 였다. 다만, 과거 손상과 선천성 변형을 동반한 경우는 제외 하였다. 또 방사선 관절 변화는 없고, 수지 측면 피부의 굴 곡 변화만 있는 경우도 제외하였다.

\section{3 통계분석}

근골격계 증상 조사와 임상의학적 진단을 통해 연구 대상 자를 정상자, 증상자 및 상지 질환자로 구분하고, 연구 대상 자의 일반적 특성에 따른 분포를 교차분석 $\left(\chi^{2}\right.$ 검정 $)$ 을 통해
살펴보았다. 증상자는 지난 주 동안 상지 증상을 호소하였으 나 임상적인 질환자로 진단받지 않은 경우로 한하였다. 그 리고 각각 $\mathrm{DASH}$ 의 평가의 구성요소별로 점수화한 결과를 가지고 일원배치 분산분석을 통해 비교하였다. 또한 근로자 의 일반적 특성과 작업환경 특성에 따른 DASH 전체점수를 막대도표로 나타내고 제반 특성에 따른 동작수행능력의 차 이는 독립표본 $\mathrm{T}$ 검정을, 근골격계 건강 상태에 따른 차이 는 일원배치 분산분석을 통한 $p$ 값을 제시하였다. 모든 통계 량의 유의수준은 0.05로 하였으며 유의확률값이 유의수준 이하일 때 통계학적으로 의미가 있는 것으로 하였다. 자료에 대한 통계분석은 Version 12.0 SPSS 통계프로그램(SPSS Inc., USA) 을 사용하였다.

\section{3. 연구 결과}

\section{1 연구 대상 근로자의 근골격계 증상/질환 여부에 따 른 일반적 특성}

조사 대상 근로자는 성별로 남성 25명, 여성 47명, 연령 별로 50세 미만 42명, 50세 이상 30명, 근무 기간별로 10 년 미만 36 명, 10 년 이상 36 명, 결혼 여부는 미혼 5 명, 기 혼 67 명, 여가취미활동은 있음 17 명, 없음 55 명, 가사노동 시간은 1 시간 미만 30 명, 1 시간 이상 42 명, 과거 질병력은 없음 63 명, 있음 8 명, 과거 사고력은 없음 55 명, 있음 16 명, 육체적 부담 정도는 견딜만함 33명, 힘듦 39 명이었다. 증상 및 근골격계 질환 진단 결과 정상은 27 명, 증상만 있는 경 우는 19 명, 근골격계 질환으로 진단받은 자는 26 명이었다. 조사 대상 근로자의 일반적 특성에 따른 근골격계 증상 및 질환은 결혼 여부, 과거 질병력 및 사고력을 제외하고 성, 연령, 근무 기간, 여가취미활동, 가사활동시간, 육체적 부담 정도에서 통계적으로 유의한 차이가 있었다. 즉, 여성에서, 연령이 많을수록, 근무 기간이 길수록, 여가취미활동이 없을 수록, 가사활동시간이 길수록, 그리고 육체적 부담 정도가 힘들수록 정상자보다 근골격계 증상자와 질환자가 많았다 (표 1).

\section{2 연구 대상 근로자의 근골격계 증상/질환 여부에 따 른 DASH 점수 일반적 특성}

조사 대상자의 근골격계 증상 및 질환 여부에 따라 DASH 의 구성요소(동작수행능력 제한, 사회활동 제한, 일상활동 제한, 상지 증상, 수면장애, 심리적 영향, 일/작업 관련 제한, 스포츠/예술활동 관련 제한) 점수 및 전체점수(선택사항 일/작업 관련 및 스포츠/예술활동 관련 제한 - 을 제외한 
표 1. 연구 대상자의 일반적 특성에 따른 근골격계 증상 및 질환

\begin{tabular}{|c|c|c|c|c|c|c|}
\hline 변수 & & 수 & 정상 & 증상자 & 질환자 & $p$ 값 \\
\hline 성 & $\begin{array}{l}\text { 남성 } \\
\text { 여성 }\end{array}$ & $\begin{array}{l}25 \\
47\end{array}$ & $\begin{array}{l}13(52.0) \\
14(29.8)\end{array}$ & $\begin{array}{r}10(40.0) \\
9(19.1)\end{array}$ & $\begin{array}{r}2(8.0) \\
24(51.1)\end{array}$ & .001 \\
\hline 연령(세) & $\begin{array}{l}<50 \\
\geq 50\end{array}$ & $\begin{array}{l}42 \\
30\end{array}$ & $\begin{array}{l}16(38.1) \\
11(36.7)\end{array}$ & $\begin{array}{r}17(40.5) \\
2(6.7)\end{array}$ & $\begin{array}{r}9(21.4) \\
17(56.7)\end{array}$ & .001 \\
\hline 근무 기간(년) & $\begin{array}{l}<10 \\
\geq 10\end{array}$ & $\begin{array}{l}36 \\
36 \\
\end{array}$ & $\begin{array}{l}16(44.4) \\
11(30.6)\end{array}$ & $\begin{array}{r}14(38.9) \\
5(13.9)\end{array}$ & $\begin{array}{r}6(16.7) \\
20(55.6)\end{array}$ & .002 \\
\hline 결혼 여부 & $\begin{array}{l}\text { 미혼 } \\
\text { 기혼 }\end{array}$ & $\begin{array}{r}5 \\
67\end{array}$ & $\begin{array}{r}3(60.0) \\
24(35.8)\end{array}$ & $\begin{array}{r}1(20.0) \\
18(26.9)\end{array}$ & $\begin{array}{r}1(20.0) \\
25(37.3)\end{array}$ & .550 \\
\hline 여가/취미활동 & $\begin{array}{l}\text { 있음 } \\
\text { 없음 }\end{array}$ & $\begin{array}{l}17 \\
55\end{array}$ & $\begin{array}{l}13(76.5) \\
14(25.5)\end{array}$ & $\begin{array}{r}4(23.5) \\
15(27.3)\end{array}$ & $\begin{array}{r}0(0.0) \\
26(47.3)\end{array}$ & .000 \\
\hline 평균가사노동시간 & $\begin{array}{c}0-<1 \\
\geq 1\end{array}$ & $\begin{array}{l}30 \\
42 \\
\end{array}$ & $\begin{array}{l}17(56.7) \\
10(23.8)\end{array}$ & $\begin{array}{r}7(23.3) \\
12(28.6)\end{array}$ & $\begin{array}{r}6(20.0) \\
20(47.6)\end{array}$ & .012 \\
\hline 과거 질병력 & $\begin{array}{l}\text { 없음 } \\
\text { 있음 }\end{array}$ & $\begin{array}{r}63 \\
8 \\
\end{array}$ & $\begin{array}{r}23(36.5) \\
4(50.0)\end{array}$ & $\begin{array}{r}17(27.0) \\
1(12.5)\end{array}$ & $\begin{array}{r}23(36.5) \\
3(37.5)\end{array}$ & .628 \\
\hline 과거 사고력 & $\begin{array}{l}\text { 없음 } \\
\text { 있음 }\end{array}$ & $\begin{array}{l}55 \\
16 \\
\end{array}$ & $\begin{array}{r}18(32.7) \\
9(56.3) \\
\end{array}$ & $\begin{array}{r}16(29.1) \\
2(12.5) \\
\end{array}$ & $\begin{array}{r}21(38.2) \\
5(31.3) \\
\end{array}$ & .191 \\
\hline 작업강도 & $\begin{array}{c}\text { 힘들지 않음 } \\
\text { 힘듬 }\end{array}$ & $\begin{array}{l}33 \\
39\end{array}$ & $\begin{array}{r}19(57.6) \\
8(20.5)\end{array}$ & $\begin{array}{r}5(15.2) \\
14(35.9)\end{array}$ & $\begin{array}{r}9(27.3) \\
17(43.6)\end{array}$ & .005 \\
\hline
\end{tabular}

$* \chi^{2}$ 검정

$\mathrm{DASH}$ 구성요소를 합한 전체 평균점수)는 스포츠/예술활동 을 제외하고는 모두 통계적으로 유의한 차이를 보였다. 즉 임상의학적으로 진단받은 근골격계 질환자, 근골격계 증상 자, 정상자의 순으로 동작수행능력 구성요소별 점수가 더 높 아 여러 활동상의 제한을 받고 있음을 알 수 있다. DASH의 점수 분포 특성을 보면, 근골격계 질환자에서 상지 증상(통 증, 저린감, 근력약화, 뻣뻣함) 30.6, 수면장애 26.0, 심리적 영향 25.0, 일/작업 관련의 어려움 23.0, 일상활동의 제한 15.4 , 구체적인 동작수행의 어려움 14.9 , 사회활동의 제한 14.4 , 스포츠/예술활동의 제한 8.0의 순이었다. 근골격계 질 환자나 증상자 모두 상지 증상, 심리적 영향, 일/작업 관련의 어려움과 일상활동의 제한 및 수면장애가 구체적인 동작수 행의 어려움, 사회활동의 제한 및 스포츠/예술활동의 제한보 다 더 높은 점수를 보였다(표 2).

조사 대상자의 성, 연령, 근무 기간, 결혼 여부, 여가취미 활동, 가사활동시간, 과거 질병력 및 사고력과 육체적 부담 정도에 따른 근골격계 증상 및 질환 여부별 $\mathrm{DASH}$ 전체점 수는 그림 1 과 같이 성, 결혼 여부, 과거 질병력 및 사고력 을 제외하고 통계적으로 유의한 차이가 있었다. 연령별로는 50 세 이상 군에서, 근무 기간은 10 년 이상 군에서, 여가/취 미활동은 여가/취미활동을 하지 않는 군에서, 평균 가사노 동시간은 1 시간 이상 군에서, 그리고 업무부담이 높은 군에
표 2. 연구 대상자의 DASH 문항 구성요소 점수

평균(표준편차)

\begin{tabular}{l|c|c|c|c}
\hline $\mathrm{DASH}$ 구성요소 & 정상 & 증상자 & 질환자 & $p$-값 \\
\hline 동작수행능력 제한 & 1.97 & 5.11 & 14.85 & .001 \\
& $(4.49)$ & $(6.60)$ & $(17.86)$ & \\
사회활동 제한 & 0.96 & 8.82 & 14.42 & .004 \\
& $(4.90)$ & $(17.55)$ & $(17.57)$ & \\
일상활동 제한 & 0.96 & 14.71 & 15.38 & .000 \\
& $(4.90)$ & $(17.81)$ & $(15.93)$ & \\
상지 증상 & 5.19 & 21.18 & 30.58 & .000 \\
& $(6.70)$ & $(11.11)$ & $(24.55)$ & \\
수면장애 & 1.92 & 11.11 & 25.96 & .000 \\
& $(6.79)$ & $(17.62)$ & $(29.56)$ & \\
심리적 영향 & 1.92 & 15.28 & 25.00 & .002 \\
& $(6.79)$ & $(22.91)$ & $(30.00)$ & \\
일/작업 관련 제한 & 3.91 & 14.24 & 23.00 & .002 \\
& $(5.77)$ & $(16.58)$ & $(24.85)$ & \\
스포츠/예술활동 제한 & 0.30 & 1.04 & 7.99 & .233 \\
\hline DASH 전체 점수† & $2.36)$ & $(3.61)$ & $(24.42)$ & \\
\hline
\end{tabular}

${ }^{\dagger} \mathrm{DASH}$ 전체 점수 $=$ 선택사항(일/작업, 스포츠/예술활동 관련 제 한)을 제외한 DASH 구성요소를 합한 전체 평균점수

"일원배치 분산분석(ANOVA) 

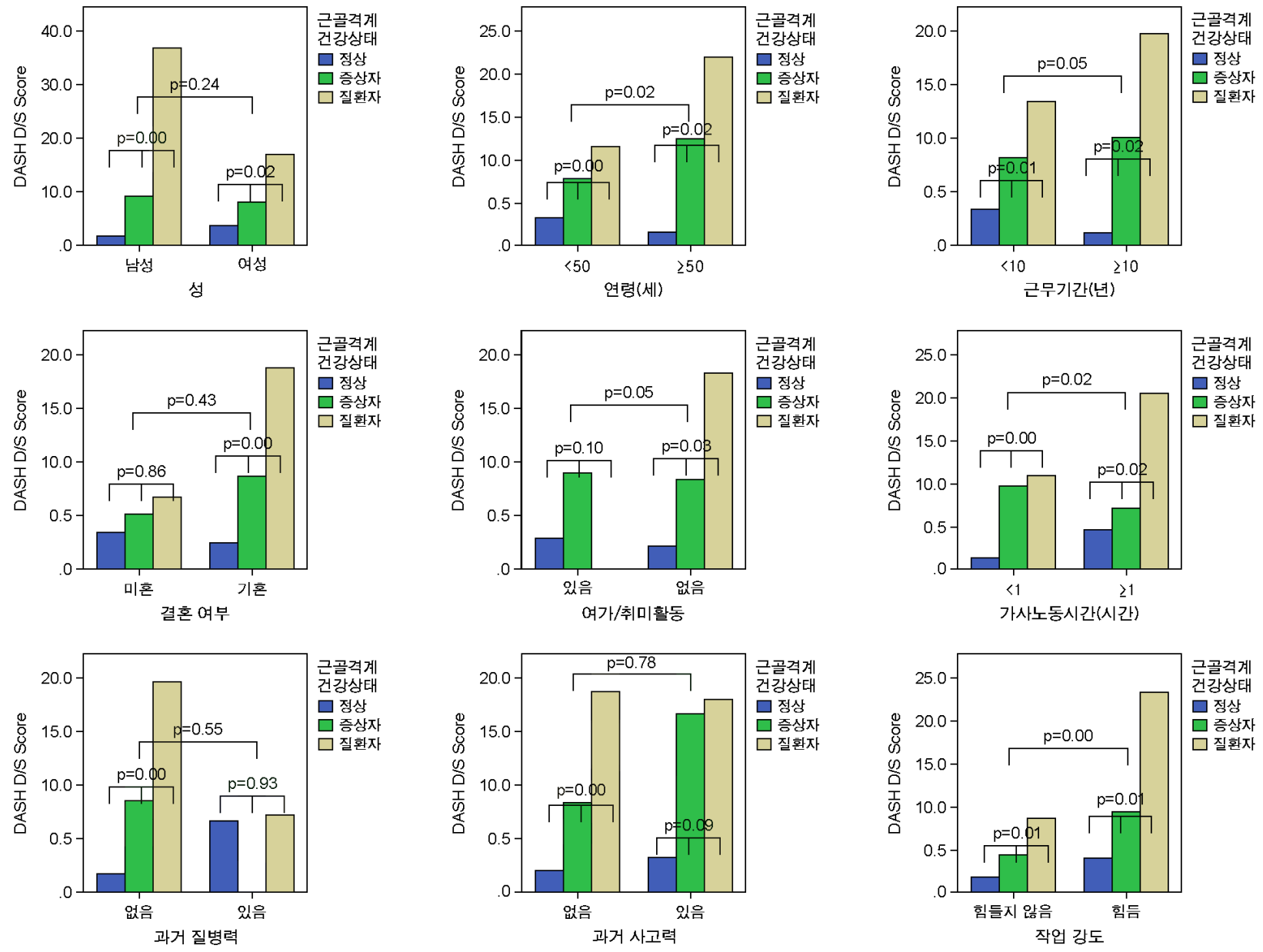

그림 1. 연구 대상자의 일반적 특성에 따른 DASH 전체점수

서 DASH 점수가 통계적으로 유의하게 높게 나타났다. 그 리고 각 군의 정상자, 근골격계 증상자 및 질환자간 $\mathrm{DASH}$ 점수는 미혼군, 여가/취미활동을 하는 군, 과거 질병력이 있 는 군과 사고력이 있는 군을 제외하고는 모두 통계적으로 유의한 점수 차이가 있었다. 즉, $\mathrm{DASH}$ 점수는 정상자, 근 골격계 증상자, 질환자 순으로 높게 나타났다(그림 1).

\section{3 연구 대상 근로자의 근골격계 증상 상태에 따른 $\mathrm{DASH}$ 점수}

근골격계 증상 조사에 따른 어깨, 팔/팔꿈치, 손/손목/손 가락의 근골격계 상지 증상을 증상의 기간, 지속 기간, 빈도 및 증상의 정도에 따라 구분하여 보면, 지난 1 년 기간 동안 의 근골격계 증상(증상 I) 호소는 55 명 $(76.4 \%)$, 지난 1 주 간 증상 (증상 II)을 호소한 근로자는 38명 $(52.8 \%)$, 통증 기간이 1 주일 이상이거나 통증의 빈도가 1 달에 1 번 이상 이면서 중간 통증 이상을 호소한 경우(증상 III)는 20명
$(27.8 \%)$, 통증 기간이 1 주일 이상이거나 통증의 빈도가 1 달에 1 번 이상이면서 중간 통증 이상이고 지난 1 주간 현 증상이 있는 경우(증상 IV)는 19 명 $(26.4 \%$ ), 통증 기간이 1 주일 이상이거나 통증의 빈도가 1 달에 1 번 이상이면서 심 한 통증 이상을 호소한 경우(증상 $\mathrm{V}$ )는 10명 (13.9\%), 통 증 기간이 1 주일 이상이거나 통증의 빈도가 1 달에 1 번 이 상이면서 심한 통증 이상이고 지난 1 주간 현 증상이 있는 경우(증상 $\mathrm{VI})$ 는 8 명 $(11.1 \%)$, 통증 기간이 1 주일 이상이 거나 통증의 빈도가 1 달에 1 번 이상이면서 심한 통증 이상 이고 지난 1 주간 현 증상이 있는 경우로서 의학적 조치(병 의원/약국 치료, 병가/산재)를 받은 자(증상 VII)는 7 명 $(9.9 \%)$ 이었다(표 3$)$.

근골격계 통증 유병 상태의 구분에 따라 $\mathrm{DASH}$ 의 구성요 소(동작수행능력 제한, 사회활동 제한, 일상활동 제한, 상지 증상, 수면장애, 심리적 영향, 일/작업 관련 제한, 스포츠/예 술활동 관련 제한) 점수 및 전체점수는 증상이 현증이고 정 도가 클수록, 그리고 의학적 조치를 받을수록 높은 점수를 
표 3. DASH 상지 근골격계 증상 유형에 따른 DASH 구성요소 점수

\begin{tabular}{|c|c|c|c|c|c|c|c|c|c|}
\hline \multirow[b]{2}{*}{ DASH 구성요소 } & \multirow[b]{2}{*}{ 정상자(17) } & \multicolumn{7}{|c|}{ 증상자 유형 } & \multirow[b]{2}{*}{ 질환자(26) } \\
\hline & & $\begin{array}{l}\text { 증상 I } \\
\text { (55) }\end{array}$ & $\begin{array}{l}\text { 증상 } \mathrm{II} \\
\text { (38) }\end{array}$ & $\begin{array}{l}\text { 증상 III } \\
\text { (20) }\end{array}$ & $\begin{array}{l}\text { 증상 IV } \\
\text { (19) }\end{array}$ & $\begin{array}{l}\text { 증상 } \mathrm{V} \\
\text { (10) }\end{array}$ & $\begin{array}{l}\text { 증상 VI } \\
\text { (8) }\end{array}$ & $\begin{array}{l}\text { 증상 } \mathrm{VII} \\
(7)\end{array}$ & \\
\hline 동작수행능력 제한 & $\begin{array}{c}1.97 \\
(4.49)\end{array}$ & $\begin{array}{c}9.60 \\
(14.22)\end{array}$ & $\begin{array}{c}12.88 \\
(15.90)\end{array}$ & $\begin{array}{c}18.82 \\
(19.31)\end{array}$ & $\begin{array}{c}19.80 \\
(19.38)\end{array}$ & $\begin{array}{c}19.21 \\
(18.09)\end{array}$ & $\begin{array}{c}23.68 \\
(18.16)\end{array}$ & $\begin{array}{c}27.43 \\
(16.66)\end{array}$ & $\begin{array}{c}14.85 \\
(17.86)\end{array}$ \\
\hline 사회활동 제한 & $\begin{array}{c}0.96 \\
(4.90)\end{array}$ & $\begin{array}{c}10.38 \\
(16.58)\end{array}$ & $\begin{array}{c}13.89 \\
(18.37)\end{array}$ & $\begin{array}{c}22.50 \\
(19.70)\end{array}$ & $\begin{array}{c}22.37 \\
(20.23)\end{array}$ & $\begin{array}{l}22.50 \\
(18.45)\end{array}$ & $\begin{array}{l}25.00 \\
(18.90)\end{array}$ & $\begin{array}{c}28.57 \\
(17.25)\end{array}$ & $\begin{array}{c}14.42 \\
(17.57)\end{array}$ \\
\hline 일상활동 제한 & $\begin{array}{c}0.96 \\
(4.90)\end{array}$ & $\begin{array}{c}12.74 \\
(15.98)\end{array}$ & $\begin{array}{c}17.36 \\
(16.71)\end{array}$ & $\begin{array}{c}23.75 \\
(17.16)\end{array}$ & $\begin{array}{c}23.68 \\
(17.63)\end{array}$ & $\begin{array}{c}27.50 \\
(18.45)\end{array}$ & $\begin{array}{l}28.13 \\
(20.86)\end{array}$ & $\begin{array}{c}32.14 \\
(18.90)\end{array}$ & $\begin{array}{c}15.38 \\
(15.93)\end{array}$ \\
\hline 상지 증상 & $\begin{array}{c}5.19 \\
(6.70)\end{array}$ & $\begin{array}{l}24.06 \\
(19.69)\end{array}$ & $\begin{array}{c}30.28 \\
(20.63)\end{array}$ & $\begin{array}{l}40.53 \\
(22.72)\end{array}$ & $\begin{array}{c}41.39 \\
(23.06)\end{array}$ & $\begin{array}{l}43.89 \\
(24.47)\end{array}$ & $\begin{array}{c}47.86 \\
(26.59)\end{array}$ & $\begin{array}{l}51.67 \\
(26.96)\end{array}$ & $\begin{array}{c}30.58 \\
(24.55)\end{array}$ \\
\hline 수면장애 & $\begin{array}{c}1.92 \\
(6.79)\end{array}$ & $\begin{array}{l}17.13 \\
(24.68)\end{array}$ & $\begin{array}{c}23.65 \\
(26.97)\end{array}$ & $\begin{array}{c}36.25 \\
(28.65)\end{array}$ & $\begin{array}{c}38.16 \\
(28.10)\end{array}$ & $\begin{array}{c}32.50 \\
(26.48)\end{array}$ & $\begin{array}{c}37.50 \\
(26.73)\end{array}$ & $\begin{array}{c}42.86 \\
(23.78)\end{array}$ & $\begin{array}{c}25.96 \\
(29.56)\end{array}$ \\
\hline 심리적 영향 & $\begin{array}{c}1.92 \\
(6.79)\end{array}$ & $\begin{array}{c}18.06 \\
(25.89)\end{array}$ & $\begin{array}{c}25.00 \\
(28.26)\end{array}$ & $\begin{array}{c}36.25 \\
(28.65)\end{array}$ & $\begin{array}{c}38.16 \\
(28.10)\end{array}$ & $\begin{array}{c}37.50 \\
(29.46)\end{array}$ & $\begin{array}{c}40.62 \\
(29.69)\end{array}$ & $\begin{array}{c}46.43 \\
(26.73)\end{array}$ & $\begin{array}{c}25.00 \\
(30.00)\end{array}$ \\
\hline 일/작업 관련 제한 & $\begin{array}{c}3.91 \\
(5.77)\end{array}$ & $\begin{array}{l}17.65 \\
(20.60)\end{array}$ & $\begin{array}{c}22.22 \\
(22.63)\end{array}$ & $\begin{array}{c}34.87 \\
(23.69)\end{array}$ & $\begin{array}{c}35.42 \\
(24.25)\end{array}$ & $\begin{array}{c}41.25 \\
(22.86)\end{array}$ & $\begin{array}{c}41.41 \\
(24.54)\end{array}$ & $\begin{array}{c}44.64 \\
(24.59)\end{array}$ & $\begin{array}{c}23.00 \\
(24.85)\end{array}$ \\
\hline 스포츠/예술활동 제한 & $\begin{array}{c}0.30 \\
(1.36)\end{array}$ & $\begin{array}{c}4.64 \\
(17.76)\end{array}$ & $\begin{array}{c}6.51 \\
(21.29)\end{array}$ & $\begin{array}{c}14.38 \\
(32.01)\end{array}$ & $\begin{array}{c}14.38 \\
(32.01)\end{array}$ & $\begin{array}{c}28.75 \\
(42.30)\end{array}$ & $\begin{array}{c}35.94 \\
(45.18)\end{array}$ & $\begin{array}{c}47.92 \\
(46.91)\end{array}$ & $\begin{array}{c}7.99 \\
(24.42)\end{array}$ \\
\hline $\mathrm{DASH}$ 전체 점수 & $\begin{array}{c}2.43 \\
(3.99)\end{array}$ & $\begin{array}{c}12.58 \\
(14.70)\end{array}$ & $\begin{array}{c}16.61 \\
(16.12)\end{array}$ & $\begin{array}{c}23.78 \\
(19.06)\end{array}$ & $\begin{array}{c}24.73 \\
(19.15)\end{array}$ & $\begin{array}{c}24.48 \\
(18.65)\end{array}$ & $\begin{array}{c}28.62 \\
(19.24)\end{array}$ & $\begin{array}{c}32.56 \\
(17.72)\end{array}$ & $\begin{array}{c}18.25 \\
(18.58)\end{array}$ \\
\hline
\end{tabular}

증상 I : 지난 1 년간 기간 증상 호소

증상 II : 지난 1 주간 현 증상 호소

증상 III : 통증 기간이 1 주일 이상이거나 통증의 빈도가 1 달에 1 번 이상이면서 중간 통증 이상 호소

증상 IV : 증상 III + 지난 1 주간 현 증상 호소(증상 II)

증상 $\mathrm{V}$ : 통증 기간이 1 주일 이상이거나 통증의 빈도가 1 달에 1 번 이상이면서 심한 통증 이상 호소

증상 $\mathrm{VI}$ : 증상 $\mathrm{V}+$ 지난 1 주간 현 증상 호소

증상 VII: 증상 $\mathrm{V}+$ 지난 1 주간 현 증상 호소 + 의학적 조치(병의원/약국 치료, 병가/산재)

DASH 전체점수 $=$ 선택사항(일/작업, 스포츠/예술활동 관련 제한)을 제외한 DASH 구성요소를 합한 전체 평균점수

보이고 있었다. 조사 대상자의 근골격계 상지 증상 여부와 근골격계 질환 진단에 따른 DASH 문항 구성요소별 점수 는 증상 $\mathrm{VII}$, 증상 $\mathrm{VI}$, 증상 $\mathrm{V}$, 증상 $\mathrm{IV}$, 증상 $\mathrm{III}$, 근골격 계 질환자, 지난 1 년 증상 호소자(증상 II), 지난 1 주 증상 호소자(증상 I), 정상자의 순이었으며, DASH 구성요소별 로는 약간의 차이는 있으나 대체로 상지 증상, 일/작업 관련 영향, 심리적 영향, 수면장애, 일상활동 제한, 사회활동 제한, 동작수행능력의 제한 순이었다(표 3).

\section{4 근골격계 질환 사례와 질환 특성에 따른 DASH 점수}

주방용 후드 조립공정 22 명과 토글공정 근로자 50 명에 대한 임상의학적 진단 결과를 종합하면 다음과 같다. 첫째, 72 명 중에서 상지의 근골격계 질환 진단을 받은 근로자는 26 명으로 유병률은 $36.1 \%$ 이었다. 둘째, 병명은 수지관절의 관절염 및 변형이 14 명 (19.4\%)으로 가장 많았으며, 그 다 음으로 외 · 내측상과염과 근막통증후군이 각각 5 명 $(6.9 \%)$, 수근관증후군 3 명 $(4.2 \%)$, 기타 이두박건초염, 드꾀르벵병
표 4. 연구 대상자의 근골격계 질환 분포

\begin{tabular}{l|rr}
\multicolumn{2}{l|}{ 빈도(\%) } \\
\hline 상지 질병명 & \multicolumn{2}{|c}{ 질병자 수 } \\
\hline 수부 지관절의 골관절염/관절변형* & $14(19.4)$ & \\
제2수지 원위지관절 & & $5(115.3)$ \\
제3수지 근위지관절 & & $4(5.9)$ \\
제3수지 원위지관절 & & $1(1.4)$ \\
제2수지 근위지관절 & & $2(2.8)$ \\
제1지 지절관절 & & \\
외/내상과염 & $5(6.9)$ & \\
근막통증후군 & $5(6.9)$ & \\
수근관증후군 & $3(4.2)$ \\
기타** & $6(8.4)$ & \\
전체 & $26(36.1)$ \\
\hline
\end{tabular}

* 관절변형: 관절간격 협소화, 골극형성, 아탈구, 각형성, 관절유합 ** 이두박건초염, 드꿰르벵병, 방아쇠 무지 등 
표 5. 상지 근골격계 질환자의 병명과 DASH 점수

\begin{tabular}{|c|c|c|c|c|c|c|c|c|}
\hline & \multirow{2}{*}{ 상지 근골격계 질환 병명 } & \multirow{2}{*}{ 성 } & \multirow{2}{*}{$\begin{array}{l}\text { 연령 } \\
\text { (세) }\end{array}$} & \multirow{2}{*}{$\begin{array}{c}\begin{array}{c}\text { 근무 기간 } \\
\text { (년) }\end{array} \\
\end{array}$} & \multicolumn{3}{|c|}{ DASH } & \multirow{2}{*}{ 회사 } \\
\hline & & & & & 기능 & 증상 & 일/작업 & \\
\hline 1 & 근막통증후군(능형근) & 여 & 34 & 3.3 & 1.2 & 25.0 & 25.0 & A \\
\hline 2 & 근막통증후군(능형근), 이두박건초염 & 여 & 45 & 13.8 & 14.3 & 30.0 & - & A \\
\hline 3 & 근막통증후군(능형근) & 여 & 52 & 17.9 & 4.8 & 0.0 & 0.0 & B \\
\hline 4 & 근막통증후군(삼두박근) & 여 & 54 & 16.1 & 1.2 & 15.0 & 6.3 & B \\
\hline 5 & 측부인대 비대 & 여 & 47 & 5.0 & 13.1 & 25.0 & 18.8 & B \\
\hline 6 & 만성 요수근 인대 염좌 & 여 & 45 & 7.7 & 16.7 & 25.0 & 6.3 & B \\
\hline 7 & 방아쇠 무지 & 여 & 47 & 15.3 & 20.2 & 5.0 & 6.3 & $\mathrm{~B}$ \\
\hline 8 & 외상과염, 관절변형(제3수지 원위지관절) & 여 & 53 & 10.5 & 6.0 & 35.0 & 56.3 & B \\
\hline 9 & 내상과염, 드꿰르벵병 & 여 & 53 & 15.3 & 13.1 & 30.0 & 25.0 & B \\
\hline 10 & 내상과염, 주두점 액낭염 & 여 & 56 & 14.3 & 32.5 & 50.0 & 50.0 & B \\
\hline 11 & 수근관증후군 & 여 & 43 & 5.0 & 3.6 & 20.0 & 0.0 & $\mathrm{~B}$ \\
\hline 12 & 수근관증후군 & 여 & 46 & 5.0 & 10.7 & 25.0 & 18.8 & B \\
\hline 13 & 수근관증후군, 관절변형(제2수지 원위지관절) & 여 & 49 & 14.3 & 2.5 & 25.0 & 6.3 & B \\
\hline 14 & 골관절염(제2, 3수지 원위지관절) & 여 & 49 & 15.5 & 0.0 & 5.0 & 0.0 & B \\
\hline 15 & 관절변형(제3수지 근위지관절) & 여 & 50 & 13.3 & 38.1 & 75.0 & 68.8 & $\mathrm{~B}$ \\
\hline 16 & 골관절염(제1지 지절관절, 제2수지 원위지관절) & 여 & 50 & 13.0 & 56.6 & 75.0 & 56.3 & A \\
\hline 17 & 골관절염(제1지 지절관절, 제2수지 원위지관절) & 여 & 53 & 15.3 & 0.0 & 30.0 & 6.3 & B \\
\hline 18 & 골관절염(제2수지 원위지관절), 외상과염 & 남 & 53 & 13.0 & 51.2 & 70.0 & 68.8 & A \\
\hline 19 & 골관절염(제2수지 원위지관절) & 여 & 54 & 12.8 & 0.0 & 10.0 & 0.0 & B \\
\hline 20 & 골관절염(제3수지 근위지관절) & 여 & 54 & 15.5 & 0.0 & 15.0 & 6.3 & B \\
\hline 21 & 골관절염(제2수지 원위지관절) & 여 & 54 & 14.0 & 56.6 & 75.0 & 56.3 & A \\
\hline 22 & 관절변형(제3수지 원위지관절), 외상과염, 근막통증후군(능형근) & 여 & 55 & 15.3 & 23.7 & 75.0 & 50.0 & B \\
\hline 23 & 관절변형(제2, 3수지 원위지관절) & 여 & 56 & 15.0 & 2.4 & 0.0 & 0.0 & B \\
\hline 24 & 골관절염(제2수지 원위지관절), 이두박건초염 & 남 & 56 & 9.5 & 11.9 & 35.0 & 43.8 & B \\
\hline 25 & 관절변형(제2수지 원위지관절) & 여 & 57 & 15.3 & 6.0 & 10.0 & 0.0 & B \\
\hline 26 & 관절변형(제2, 3수지 원위지관절) & 여 & 58 & 21.0 & 0.0 & 10.0 & 0.0 & $\mathrm{~B}$ \\
\hline
\end{tabular}

* 관절변형: 관절간격 협소화, 골극형성, 아탈구, 각형성, 관절유합

$\mathrm{A}$ : 주방기기 제조회사, $\mathrm{B}$ : 피혁제품 제조회사

(de Quervain's disease), 방아쇠 무지 등이 있었다. 셋째, 수지관절염의 위치는 제 2 수지 원위지관절이 11 증례로 가장 많았고, 그 다음은 제3수지 근위지관절 5 례, 제 3 지 원위지관 절 4 례, 제 1 지 지절관절의 순이었다(표 4).

근골격계 질환의 26 사례의 임상의학적 진단명과 성, 연 령 및 $\mathrm{DASH}$ 점수는 표 5 와 같다. 근골격계질환의 발병의 위치(좌/우 및 양측), 질병 양태(관절질환과 근/신경질환), 그리고 질병의 신체부위(손/손가락, 팔/어깨, 상지)에 따라 우측이 좌측보다, 관절 질환이 근/신경질환보다, 손/손목/손 가락의 근골격계 질환이 팔/어깨 질환보다 DASH 점수는 높게 나타났으나 통계적으로 유의한 차이는 보이지 않았다 (그림 2).

\section{5 설문조사에 의한 근골격계 증상과 임상의학적 근골 격계 질환의 관계}

근골격계 증상과 근골격계 질환과의 관계는 통증 기간이 1 주일 이상이거나 통증의 빈도가 1 달에 1 번 이상이면서 중 간 통증 이상을 호소한 경우(증상 III)에 $75.5 \%$ 가 근골격 계 질환으로 진단받은 반면에 상지 증상을 호소하지 않는 근로자 중에서도 5 명 $(15.5 \%)$ 이 근골격계 질환을 진단받았 다. 통증 기간이 1 주일 이상이거나 통증의 빈도가 1 달에 1 번 이상이면서 심한 통증 이상을 호소한 경우(증상 $\mathrm{V}$ )에서 도 위의 결과와 비슷하게 나타났다(표 6). 

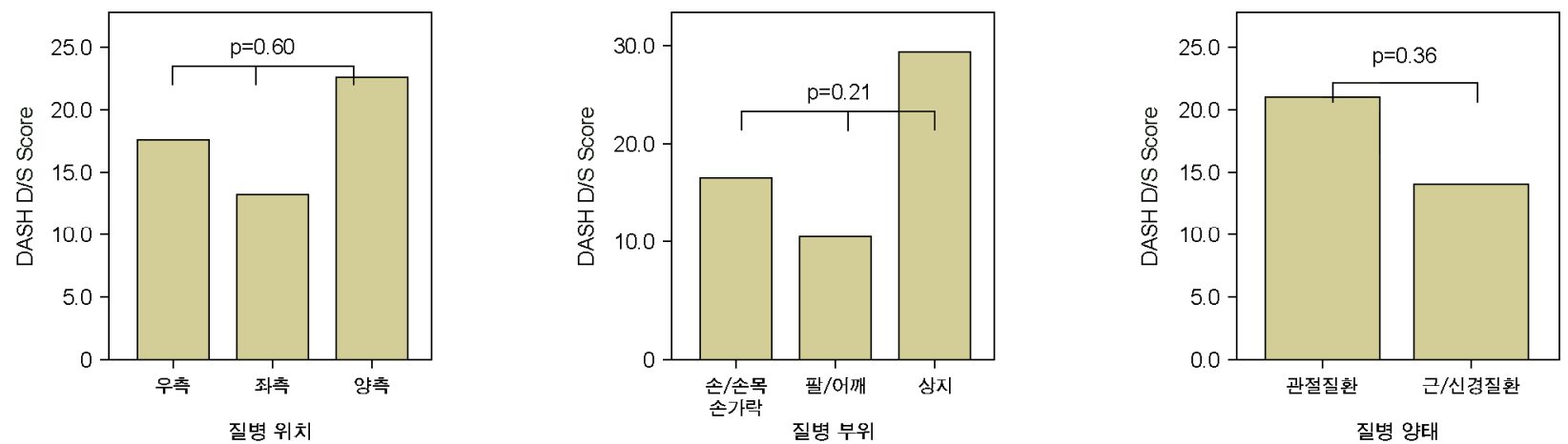

그림 2. 근골격계 질환자 특성에 따른 DASH 전체점수

표 6. 상지 근골격계 증상과 질환과의 관계

\begin{tabular}{l|c|r|r|c}
\hline & & 질환자(-) & 질환자(+) & $p$-값 \\
\hline \multirow{2}{*}{ 증상 III } & No & $41(78.8)$ & $11(21.2)$ & .000 \\
& Yes & $5(15.5)$ & $15(75.5)$ & \\
\hline \multirow{2}{*}{ 증상 V } & No & $44(71.0)$ & $18(29.0)$ & .003 \\
& Yes & $2(20.0)$ & $8(80.0)$ & \\
\hline
\end{tabular}

증상 III : 통증 기간이 1 주일 이상이거나 통증의 빈도가 1 달에 1 번 이상이면서 중간 통증 이상 호소

증상 $\mathrm{V}$ : 통증 기간이 1 주일 이상이거나 통증의 빈도가 1 달에 1 * $\chi^{2}$ 검정

\section{4. 고 찰}

근골격계 증상 또는 질환은 직업 및 비직업적인 위험요인 과 관련이 있다. 이와 같은 위험으로 연령, 성, 비만, 흡연/ 음주 등의 건강 행태, 여가/취미활동, 가사활동 및 개인질병 력 등의 개인적 위험과 직무요구, 직무의 자율성, 직무만족 등의 정신심리적 요인 및 작업의 반복성, 힘, 자세, 진동 및 한랭 등의 물리적 위험요인이 있다. 근골격계 질환과 관련 있는 전신질환으로는 류마토이드 관절염, 통풍, 루프스와 당뇨 등이 있다(Punnett과 Wegman, 2004). 이 연구에서 도 여성에서, 연령이 많을수록, 근무 기간이 길수록, 가사활 동이 길수록, 그리고 육체적 부담 정도가 힘들수록 정상자보 다도 근골격계 증상자와 질환자가 많아 기존 국내·외 연 구 결과를 뒷받침하고 있다.

이와 같은 골격계 증상/질환에 영향을 미치는 위험요인은 곧 그대로 상지의 기능장애에 영향을 미치는데, 이는 상지 의 근골격계 증상/질환이 동작수행능력, 수면장애, 심리적 영향 및 일상/사회활동을 포함한 기능장애와 활동 제한을 일으키기 때문이다(김규상 등, 2009). 실제 장애의 과정
은 인체의 기관과 신체부위의 병리적 과정 (pathology and impairment)에서 개인적/사회적 수준의 심리적/정서적/행 동학적인 전반적인 생의 만족 등 삶의 질 측면의 기능 제한 (functional limitation) 과 장애 (disability/handcap) 까지 영 향을 미치기 때문이다(Jette, 1994).

이러한 상지의 기능장애를 평가하는 도구로서 $\mathrm{DASH}$ 를 많이 활용하고 있다. $\mathrm{DASH}$ 는 삶의 질과 건강 상태의 측정 의 개념적 문헌 고찰, 전문가의 토론 및 1990 년대 이후의 기존의 양적 평가도구에 대한 개념의 재고를 통해 미국 정형 외과학회(American Academy of Orthopaedic Surgeons, $\mathrm{AAOS}$ )의 상지협력연구단(Upper Extremity Collaborative Group)에서 상지에 영향을 미치는 근골격계 건강 상태와 손상의 여러 다양한 기능상의 영향력을 측정하기 위해 개발 되었다(Solway 등, 2002).

$\mathrm{DASH}$ 는 여러 집단 또는 개인에서 상지 근골격계 질환의 영향을 비교하여 구분하고, 치료 개입의 효과나 또는 시간의 경과에 따른 변화를 평가하기 위한 목적으로 사용되고 있 다. 그러나 $\mathrm{DASH}$ 는 근골격계 증상자와 상지 근골격계 질 환자 중심의 적용을 넘어 일반 인구 집단, 산업체의 근로자 와 또 근골격계 질환 이외의 타 질환 인구 집단에도 널리 활용되고 있다. 상지의 화상환자의 회복을 평가하는 장애 측정도구로서 QuickDASH 도구 활용 사례를 들 수 있다 (Wu 등, 2007).

근골격계 증상/질환이 심할수록 동작수행능력, 즉 일상생 활에서 상지를 사용하는데 상지의 통증, 저린감, 뺏뺏함 등 의 증상으로 또는 질환의 발병 신체부위의 운동 제한으로 인한 기능장애가 생긴다. 이 연구는 주방용 후드 조립공정과 피혁제품 제조의 토글공정 근로자에서 상지, 특히 수부 근 골격계 질환이 다수 발생하여 표준화된 측정도구를 이용한 조사 및 임상의학적 진단을 시행하여 상지 근골격계 증상 및 질환자의 발생과 분포 특성 등을 살펴보았다. 그리고 상 지 근골격계 증상/질환의 개인의 사회인구학적 특성과의 관 련성 및 동작수행능력의 제한에 어떠한 영향을 미치는지 분 
석하고자 DASH라는 설문지를 적용하여 DASH 항목과 각 구성 부문별 점수를 살펴보고, 근골격계 증상 여부와 정도에 따른 내부 집단별로 비교하고, 또 동작수행능력에 영향을 미치는 요인을 분석하였다.

$\mathrm{DASH}$ 의 구성요소별 각 문항에 대한 척도상의 점수로 환산하여 평가하였을 때 질환자와 증상자에서 동작수행능력 구성요소별 점수가 더 유의하게 높아 여러 활동상의 제한을 받고 있으며, 상지 증상, 심리적 영향, 일/작업 관련의 어려 움과 일상활동의 제한 및 수면장애가 구체적인 동작수행의 어려움, 사회활동의 제한 및 스포츠/예술활동의 제한보다 더 높은 점수를 보여, 증상/질환의 특성과 관련이 있거나 외국 의 환자만을 대상으로 한 결과와 차이를 보여 이에 대한 고 찰이 필요하다고 할 수 있다.

이는 증상의 정도에 따른, 즉 통증 유병 상태의 구분에 따른 결과에서 증상이 현증이고 정도가 클수록, 그리고 의 학적 조치를 받을수록 높은 $\mathrm{DASH}$ 점수를 보여 적용시 유 의하여야 하나 DASH 구성요소별 점수는 대체로 상지 증상, 일/작업 관련 영향, 심리적 영향, 수면장애, 일상활동 제한, 사회활동 제한, 동작수행능력의 제한 순이었다.

이 연구 대상의 근골격계 질환자는 수부 이외에도 다른 신체부위의 근골격계 증상을 호소하고 질환에 이환되었지만 유의하게 손목과 손가락에 집중되어 나타났다. 특히 수지관 절의 변형을 동반한 골관절염의 사례가 많았다.

관절염은 다른 근골격계 질환과 더불어 성인에서 나타나 는 장애의 가장 흔한 원인으로 알려져 있다. 만성 관절염의 대표적인 종류로는 퇴행성 골관절염, 류마티스 관절염, 강직 성 척추염, 통풍성 관절염 등이 있으며, 이 중에서 골관절염 은 관절연골의 국소적인 퇴행성 변화, 연골하골의 비대, 주 변 골연부의 과잉 골형성, 관절의 변형을 특징으로 하고 이 차적으로 활액 조직 염증을 동반한다(Threlkeld와 Currier, 1988). 임상적으로는 통증, 관절변형을 일으키고, 근력 및 관절가동범위가 감소되며, 음식준비 등의 도구적 일상활동 뿐만 아니라 기초적인 옷입기 등의 일상생활활동에도 어려 움을 격게 된다.

골관절염은 50세 이후를 기준으로 급격히 증가하며 남성 보다는 여성에서 발생율이 높으며, 비만, 호르몬의 영향, 흡 연, 고혈압 및 당뇨 등이 위험인자로서 관련성이 있다고 하 며, 직업적으로 관절의 반복적인 무리한 사용과 골관절염간 의 관련성도 많이 제기되어 왔다. 수부 골관절염의 발생 위 험요인 또한 일반적인 골관절염과 같이 성(여성>남성), 연 령, 직업 및 작업, 가사활동(여성), 병력(비만, 당뇨, 갑상선 저하증 등)을 들 수 있다.

이 연구의 대상 근로자에서 수부 근골격계 질환도 거의 대부분 여성에서 연령이 증가할수록, 장기간 근무할수록, 평균 가사노동시간이 길수록 그리고 육체적 부담 정도가 클
수록 유병률은 높게 나타났다. 그러나 이와 같은 인구사회학 적 요인 이외에도 직업적으로 인간공학적 위험(고반복, 접촉 스트레스, 부적절한 작업 자세, 힘 등)이 높은 주방용 후드 조립 및 토글작업을 십수년 수행하여 왔으며, 특히 토글작 업 근로자의 수부 지관절의 관절염은 토글작업의 작업 특성 (제3지 근위지관절-과굴곡 상태, 제2지 원위지관절-요사 위 방향의 집기동작, 3,000 7,000회의 손가락 및 수지관 절의 과다한 반복작업)이 직접적으로 근골격계 질환의 발생 에 영향을 미쳤다고 볼 수 있다(김규상 등, 2007).

이 연구 결과를 가지고 결론적으로 다음과 같은 제언을 할 수 있다. 첫째로, 근골격계 증상 발현과 동작수행능력에 영향을 미치는 요인과 관련하여 개인적 요인, 작업환경 및 인간공학적 요인 등이 복합적으로 영향을 미침을 알 수 있 어 근골격계 질환의 예방을 위한 종합적인 관리(의학적 관 리, 작업관리 및 작업환경관리 -인간공학적 개선)가 필요 하다. 둘째로, 우리나라에서도 사업장 근로자를 대상으로 특 히 근골격계 증상자 또는 질환자를 대상으로 $\mathrm{DASH}$ 를 작업 관리, 의학적 치료, 재활 등의 평가에도 적용할 수 있을 것 이다.

\section{5. 결 론}

이 연구는 주방용 후드 조립공정과 피혁제품 제조의 토글 공정 근로자에서 상지, 특히 수부 근골격계 질환이 다수 발 생하여 표준화된 측정도구를 이용한 조사 및 임상의학적 진 단을 시행하여 상지 근골격계 증상 및 질환자의 발생과 특 성 등을 살펴보고, 상지 근골격계 증상과 질환의 개인의 사 회인구학적 특성과의 관련성 및 동작수행능력의 제한에 어 떠한 영향을 미치는지 분석하고자 하였다.

주방용 후드 조립공정의 22 명과 피혁제품 제조의 토글공 정 근로자 50명을 대상으로 근골격계 증상, 동작수행능력의 제한을 조사하고, 이학적 검사, 방사선 검사 및 근 - 신경전 도 검사 등 근골격계 질환의 임상의학적 진단을 시행하였다.

조사 결과, 여성, 고연령, 장기간의 근무 기간, 긴 평균 가 사노동시간, 여가/취미활동을 하지 않을수록, 그리고 육체적 부담이 클수록 근골격계 질환자가 많았으며, 또 $\mathrm{DASH}$ 점 수도 유의하게 높게 나타났다. 임상의학적으로 진단받은 근 골격계 질환자, 근골격계 증상자, 정상자의 순으로 동작수행 능력 구성요소별 점수가 더 높아 여러 활동상의 제한을 받 고 있었으며, 상지 증상, 수면장애, 심리적 영향, 일/작업 관 련의 어려움, 일상활동의 제한, 구체적인 동작수행의 어려움, 사회활동의 제한, 스포츠/예술활동의 제한 순의 점수 분포 를 보이고 있었다. 근골격계 통증 유병 상태의 구분에 따라 
$\mathrm{DASH}$ 의 구성요소 점수 및 전체점수는 증상이 현증이고 정도가 클수록, 그리고 의학적 조치를 받을수록 높은 점수 를 보이고 있었다. 조사 대상 72 명 중에서 상지 근골격계 질환 진단을 받은 근로자는 26 명으로 유병률은 $36.1 \%$ 로, 병명은 수지관절의 관절염 및 변형이 14 명 $(19.4 \%)$ 으로 가 장 많았으며, 그 다음으로 외 · 내측상과염이 5명 (6.9\%), 근 막통증후군 5명 (6.9\%), 수근관증후군 3명 (4.2\%) 였고, 기 타 이두박건초염, 드꿰르벵병, 방아쇠 무지 등이 있었다.

이 연구 결과를 통해 근골격계 증상 및 질환은 개인의 사 회인구학적 특성과 관련이 있으며, 근골격계 질환 유병자에 서 상지의 높은 동작수행능력 장애점수를 보였다. 근골격계 증상과 질환의 여부에 따른 동작수행능력, 사회활동과 일상 활동의 제한, 상지의 증상, 수면활동장애 등과 일/작업 관련 및 스포츠/예술활동 관련에 미치는 영향의 역학적 의의도 커 이에 대한 예방대책을 마련할 필요가 있다.

\section{참고 문헌}

김규상, 장기언, 홍창우, 특수도구 과사용으로 유발된 수지관절변 형 및 수부 근골격계 질환, 한국의 산업의학, 46(4), 159-169, 2007.

김규상, 홍창우, 김민기, 제조업 종사 근로자의 동작수행능력에 영향을 미치는 요인, 대한산업의학회지, 21(2), 115-130, 2009.

Beaton, D. E., Cole, D. C., Manno, M., Bombardier, C., Hogg-Johnson, S. and Shannon, H. S., Describing the burden of upper-extremity musculoskeletal disorders in newspaper workers: What differences do case definitions make? J Occup Rehabil, 10(1), 39-53, 2000.

Beaton, D. E., Davis, A. M., Hudak, P. and McConnel, S., The DASH (disability of the arm, shoulder and hand) outcome measure: What do we know about it now? Br J Hand Ther, 6(4), 109- 118, 2001.

Beaton, D. E., Katz, J. N., Fossel, A. H., Wright, J. G., Tarasuk, V. and Bombardier, C., Measuring the whole or the parts? Validity, reliability and responsiveness of the disabilities of the arm, shoulder and hand outcome measure in different regions of the upper extremity, $J$ Hand Ther, 14(2), 128-146, 2001.

Fan, Z. J., Smith, C. K. and Silverstein, B. A., Assessing validity of the quick DASH and SF-12 as surveillance tools among workers with neck or upper extremity musculoskeletal disorders, $J$ Hand Ther, 21, 354-365, 2008.

Fayad, F., Lefevre-Colau, M-M., Mace, Y., Gautheron, V., Fermanian, J., Roren, A., Roby-Brami, A., Revel, M. and Poiraudeau, S., Responsiveness of the French version of the disability of the arm, shoulder and hand questionnaire (F-DASH) in patients with orthopaedic and medical shoulder disorders, Joint Bone Spine, 75, 579-584, 2008.
Jette, A. M., Physical disablement concepts for physical therapy research and practice, Physical Therapy, 74(5), 380-386, 1994.

Kitis, A., Celik, E., Aslan, U. B. and Zencir, M., DASH questionnaire for the analysis of musculoskeletal symptoms in industry workers: a validity and reliability study, Appl Ergon, 40, 251-255, 2009.

Lucado, A. M., Li, Z., Russell, G. B., Papadonikolakis, A. and Ruch, D. S., Changes in impairment and function after static progressive splinting for stiffness after distal radius fracture, $J$ Hand Ther, 21, 319-325, 2008.

McDermid, J. C., Drosdowech, D. and Faber, K., Responsiveness of selfreport scales in patients recovering from rotator cuff surgery, $J$ Shoulder Elbow Surg, 15(4), 407-414, 2006.

Punnett, L. and Wegman, D. H., Work-related musculoskeletal disorders: the epidemiologic evidence and the debate, J Electromyogr Kinesiol, 14(1), 13-23, 2004

Solway, S., Beaton, D. E., McConnell, S. and Bombardier, C., The DASH Outcome Measure User's Manual, Second Edition, Toronto: Institute for Work \& Health, 2002.

Threlkeld, A. J. and Currier, D. P., Osteoarthritis. Effects on synovial joint tissues, Phys Ther, 68(3), 364-370, 1988.

Turchin, D. C., Beaton, D. E. and Richards, R. R., Validity of observerbased aggregate scoring systems as descriptors of elbow pain, function, and disability, J Bone Joint Surg, 80A(2), 154-162,1998.

Wong, Y. P., Fung, K. K., Chu, M. L. and Chan, K. Y., The use of disabilities of the arm, shoulder, and hand questionnaire in rehablitation after acute traumatic hand injuries, J Hand Ther, 20, 49-56, 2007.

Wu, A., Edgar, D. W. and Wood, F. M., The QuickDASH is an appropriate tool for measuring the quality of recovery after upper limb burn injury, Burns, 33, 843-849, 2007.

(1) 저자 소개

* 김 규 상 kobawoo@kosha.net 연세대학교 의과대학 보건학박사

현 재: 한국산업안전보건공단 산업안전보건연구원 연구위원 관심분야: 산업의학, 산업보건, 근골격계질환

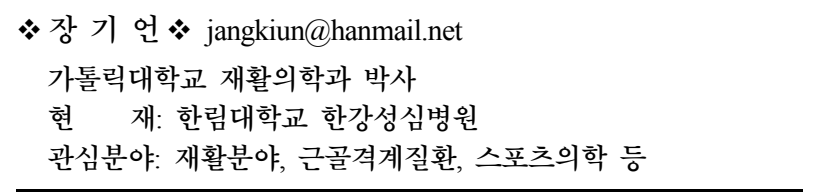

논 문 접 수 일 (Date Received) : 2010년 01월 14일

논 문 수 정 일 (Date Revised) :2010년 03월 12일

논문게재승인일 (Date Accepted) : 2010년 03월 19일 